\title{
Correction to: Nutlin-3 cooperates with doxorubicin to induce apoptosis of human hepatocellular carcinoma cells through p53 or p73 signaling pathways
}

\author{
Tongsen Zheng ${ }^{1} \cdot$ Jiabei Wang $^{1} \cdot$ Xuan Song ${ }^{1} \cdot$ Xianzhi Meng $^{1} \cdot$ Shangha Pan ${ }^{1} \cdot$ Hongchi Jiang $^{1} \cdot$ Lianxin Liu $^{1}$
}

Published online: 2 February 2021

๑) Springer-Verlag GmbH Germany, part of Springer Nature 2021

\section{Correction to: \\ J Cancer Res Clin Oncol (2010) 136:1597-1604 https://doi.org/10.1007/s00432-010-0817-8}

In the original article, there was one misplaced image in Fig. 4a (the representative MDM2 blot in Hep3B cells). The corrected Fig. 4 is shown below. The authors declare that the correction does not affect the results or conclusions of this article. We sincerely apologize for any inconvenience or misunderstanding that this error may have caused.

The original article can be found online at https://doi.org/10.1007/ s00432-010-0817-8.

Lianxin Liu

liulianxin@medmail.com.cn

1 Department of General Surgery, The First Affiliated Hospital

of Harbin Medical University, No. 23 Youzheng Street,

Harbin 150001, Heilongjiang Province, China 


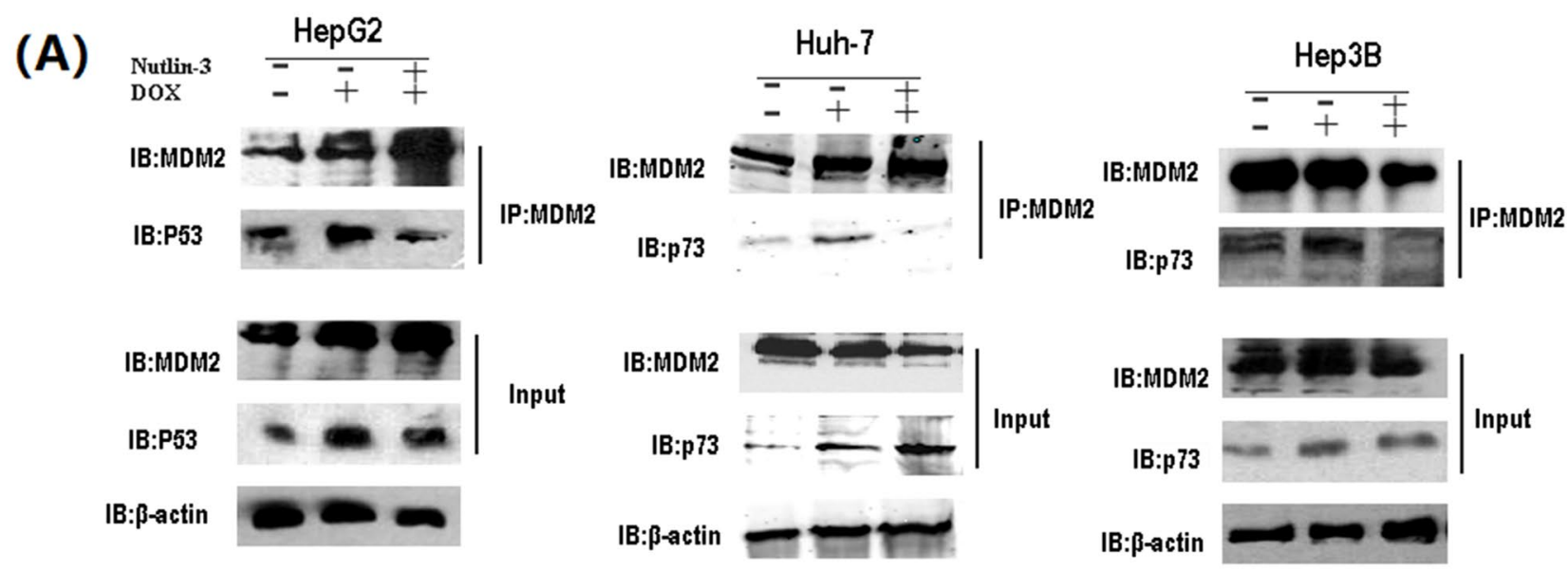

(B)

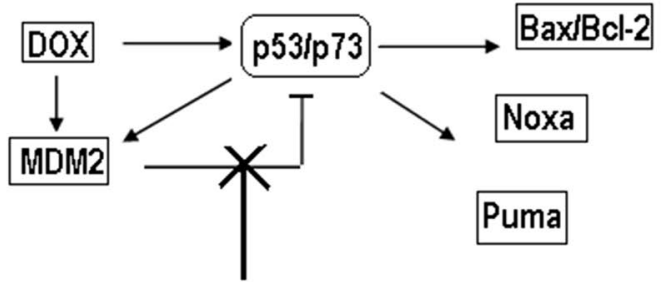

\section{$\square$ Apoptosis}

Nutlin-3

Fig. 4 a Nutlin-3 inhibits binding of p53 and p73 to MDM2 when combined with DOX and increases p53 and p73 activity in human HCC cell lines. Untreated HCC cells, cells treated with $1.25 \mu \mathrm{g} / \mathrm{ml}$ DOX and cells treated with DOX/Nutlin-3 $(10 \mu \mathrm{M})$ for $24 \mathrm{~h}$ were immunoprecipitated with an anti-MDM2 antibody. Immunocom- plexes were subjected to immunoblotting with anti-MDM2, p53 and p73 antibodies. Equal amounts of whole-cell lysates were blotted with the same antibodies to demonstrate equal loading. b A schematic presentation for the synergistical anticancer mechanisms of DOX/ Nutlin-3 combination in the current study

Publisher's Note Springer Nature remains neutral with regard to jurisdictional claims in published maps and institutional affiliations. 